\title{
Bacteriophage Removal Efficiency of In-line Coagulation with Ceramic Membrane Filtration
}

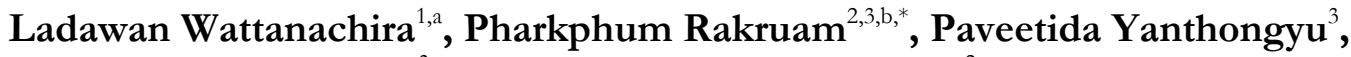 \\ Phantipa Chaimongkol ${ }^{3}$, and Suraphong Wattanachira ${ }^{2}$ \\ 1 Department of Environmental Engineering, Faculty of Engineering, Rajamangala University of \\ Technology Lanna, Chiang Mai, Thailand 50300 \\ 2 Department of Environmental Engineering, Faculty of Engineering, Chiang Mai University, Chiang Mai, \\ Thailand 50200 \\ 3 Center of Excellence on Hazardous Substance Management (HSM), Chulalongkorn University, Bangkok, \\ Thailand 10330 \\ E-mail: alwattanachira@gmail.com, bpharkphum@eng.cmu.ac.th (Corresponding author)
}

\begin{abstract}
The main objectives of this study are to evaluate the removal efficiency of bacteriophage $\mathrm{Q} \beta$ using in-line coagulation with ceramic membrane filtration at different coagulant dosages, ceramic membrane pore sizes and initial bacteriophage $Q \beta$ concentrations. Raw water was collected from the Ping River, Chiang Mai, Thailand, and spiked with bacteriophage $\mathrm{Q} \beta$ to prepare an initial concentration of $8 \times 10^{6} \mathrm{PFU} / \mathrm{ml}$. According to the resulted, it was found that the smaller pore sizes membrane yield higher bacteriophage $\mathrm{Q} \beta \log$ removal. However, the use of a ceramic membrane alone could not remove bacteriophage $\mathrm{Q} \beta$ completely. In-line coagulation combined with ceramic membrane filtration was conducted. The optimal polyaluminum chloride (PACl) doses for the 1.0, 0.5 and $0.1 \mu \mathrm{m}$ pore size membranes were $2.5,2.0$ and $1.5 \mathrm{mg}-\mathrm{Al} / \mathrm{L}$, respectively. Bacteriophage $\mathrm{Q} \beta$ removal at the optimal PACl dose was more than $6.7 \log$ in all cases. The results of effect of different initial bacteriophage $\mathrm{Q} \beta$ concentration on the removal efficiency showed that in-line coagulation with ceramic membrane at all pore sizes can completely remove bacteriophage $\mathrm{Q} \beta$ when the initial concentration was low $\left(5 \times 10^{5}\right.$ $\mathrm{PFU} / \mathrm{ml})$. However, the higher initial bacteriophage $\mathrm{Q} \beta$ concentrations $\left(4 \times 10^{6}\right.$ and $8 \times 10^{7}$ $\mathrm{PFU} / \mathrm{ml}$ ) required a higher $\mathrm{PACl}$ dose to obtain effective bacteriophage $\mathrm{Q} \beta$ removal.
\end{abstract}

Keywords: Bacteriophage, ceramic membrane, in-line coagulation, $\mathrm{PACl}$ coagulation.

ENGINEERING JOURNAL Volume 21 Issue 4

Received 31 August 2016

Accepted 16 December 2016

Published 31 July 2017

Online at http://www.engj.org/

DOI:10.4186/ej.2017.21.4.1 


\section{Introduction}

Human enteric viruses have been recognized as major causes of waterborne out-break which have been reported worldwide in both developed and developing countries [1, 2]. Human virus analysis requires advanced technologies and specialists. The F-specific RNA bacteriophage is an enterobacteriaceae virus of the Leviviridae family that is physically and genomically analogous to human enteric viral pathogens found in sewage. It is abundant in sewage and easy to enumerate using standardized ISO methods (ISO10705-1), making them a good prospective indicator of viral contamination in a marine environment. It has been proposed as indicators of viral contamination in the environment and used to model the behavior of human pathogen enteric viruses. F-specific RNA bacteriophage Q $\beta$ (diameter $0.023 \mu \mathrm{m}$, pI 5.3) has been used extensively as a surrogate virus for waterborne viruses because of its morphological and structural resemblance to human enteric viruses, which need to be removed during the treatment of drinking water [3-7]. In addition, its survival characteristics in aquatic environments are similar to those of human enteric viruses. The average concentrations of F-specific RNA bacteriophage that commonly found in wastewater are ranging from 1 to $5 \log 10$ plaque-forming units $(\mathrm{PFU}) / \mathrm{ml}[8-10]$ and 1 to $3 \log 10 \mathrm{PFU} / \mathrm{ml}$ in river water $[9,11-12]$

The one of the most important factor for human survival is access to the high quality of potable water [13]. Membrane filtration is the promising technology which has been used extensively all over the world for potable water production and wastewater treatment. The installation of microfiltration (MF) and ultrafiltration (UF) facilities has increased considerably over the past decade [14]. MF and UF are considered capable processes for providing better drinking water quality. The solid-liquid separation process in water treatment using ceramic membranes has garnered greater interest over the last decade [15]due to its several advantages such as its strength, resistance to acidity, thermal superiority, chemical stability and low environmental impact [16]. The membranes are used to remove particulate matter such as inorganic particles as well as microorganisms including bacteria and virus. Nevertheless, MF devices whose pore sizes are not small enough to reject smaller particles as viruses, causing health concerns [4].

The addition of a coagulant before ceramic membrane filtration is one of the possible pretreatment processes to increase treated water quality. It has been reported that some microorganisms have a tendency to be adsorbed onto the coagulated floc particles, which are retained by ceramic membranes. In-line coagulation is an application applied to small membrane systems. It is referred to the use of coagulation before membrane filtration without a sedimentation step $[17,18]$ and can enhance microorganism removal onto the membrane surface.

Thus, the objective of this study is to investigating the bacteriophage $\mathrm{Q} \beta$ removal efficiency of in-line $\mathrm{PACl}$ coagulation with ceramic membrane filtration along with the effects of the initial bacteriophage $\mathrm{Q} \beta$ concentration and $\mathrm{PACl}$ dosage.

\section{Materials and Methods}

\subsection{Raw Water}

Raw water was collected from the Ping River in Chiang Mai, Thailand, in December during the winter season. It contained a turbidity about 40-80 NTU. Raw water was transported in polyethylene tanks and stored in a refrigerator at $4^{\circ} \mathrm{C}$ before analysis. $\mathrm{pH}$ of the raw water was directly measured by a Model F-21 Horibra pH-meter. A HACH Turbidity meter Model 2100 was used to measure the turbidity of the raw water in nephelometric turbidity units (NTU). The parameters were analyzed in triplicate.

\subsection{In-line Coagulation Combined with Ceramic Membrane Filtration}

The ceramic membrane modules used in this study of nominal pore sizes of $1.0 \mu \mathrm{m}, 0.5 \mu \mathrm{m}$ and $0.1 \mu \mathrm{m}$ were provided by Metawater Co., Ltd., Japan. The ceramic membrane modules, which were installed in a stainless steel vessel vertically, were operated in dead-end mode. The purged pressure was controlled by adjusting the nitrogen gas pressure regulator. Raw water was spiked with bacteriophage $\mathrm{Q} \beta$ and mixed by using jar test apparatus at a mixing speed of $150 \mathrm{r} / \mathrm{min}$ for 60 second to prepare an initial concentration of $8.00 \times 10^{6} \mathrm{PFU} / \mathrm{ml}$. The spiked-bacteriophage $\mathrm{Q} \beta$ raw water was poured into a pressurized tank. Polyaluminum chloride $(\mathrm{PACl})$ was used as the coagulant for in-line coagulation combined with ceramic 
membrane filtration experiment. $\mathrm{PACl}$ dosage of $1.5,2.0,2.5$ and $3.0 \mathrm{mg}-\mathrm{Al} / \mathrm{L}$ were added to the spikedbacteriophage $\mathrm{Q} \beta$ raw water and immediately mixed. After that, the coagulated water in the pressurized tank was allowed to flow through an 8-meter-nylon tube prior flowing to the bottom end of the ceramic membrane module. The feeding control was regulated by nitrogen gas at a controlled pressure of $0.2 \mathrm{MPa}$ as shown in Fig. 1. The spiked- bacteriophage $\mathrm{Q} \beta$ raw water and permeate water were collected to evaluate the bacteriophage $\mathrm{Q} \beta$ removal efficiencies.

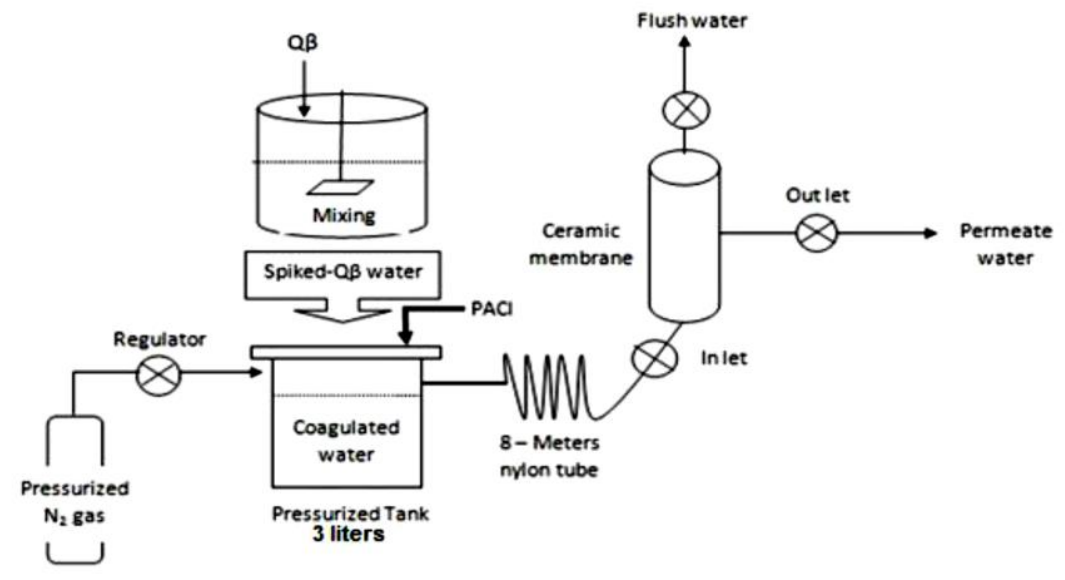

Fig. 1. Schematic diagram of in-line coagulation combined with a ceramic membrane.

\subsection{F-specific RNA Bacteriophage $\mathrm{Q} \beta$ and Bacterial Host Preparation}

The F-specific RNA bacteriophage $\mathrm{Q} \beta$ was used as a spiked model virus. Bacteriophage $\mathrm{Q} \beta$ was analyzed by an overlay plaque assay using Salmonella typhimurium WG 49 as the host strain. A WG49 host strain working culture was prepared by using the pour plate technique that uses MacConkey agar as the medium. The culture plates were incubated overnight at $37^{\circ} \mathrm{C}$. Then it was kept in the refrigerator at $4^{\circ} \mathrm{C}$ for 3 weeks. Inoculums cultures were prepared by picking up 3-6 colonies with agar from the working culture plate and adding them into the $10 \mathrm{ml}$ of the Tryptone-yeast extract-glucose-broth (TYGB). The culture was incubated with shaking for 24 hours at $37^{\circ} \mathrm{C}$. About $10 \mathrm{ml}$ of the inoculum culture could be used with 500 $\mathrm{ml}$ of the tryptone-yeast extract-glucose agar (TYGA). The concentration of the microbe was reported as $\mathrm{PFU} / \mathrm{ml}$. In addition, E. coli $\mathrm{K} 12 \mathrm{~A} / \lambda(\mathrm{F}+)$ was used as the host strain for an enumeration of the F-specific RNA bacteriophage. The procedure for enumerating E. coli K12 A/ $\lambda(\mathrm{F}+)$ is described the same as above. bacteriophage $\mathrm{Q} \beta$ stock solution at a concentration of about $10^{8} \mathrm{PFU} / \mathrm{ml}$ was sub-cultured in the $\mathrm{LB}$ broth feed with E. coli K12 A/ $\lambda(\mathrm{F}+)$ every 2 weeks.

\subsection{Overlay Plaque Essay}

The procedures used were in accordance with the standardized protocol (ISO, 1997). The WG49 host strain was incubated in TYGB for $18 \pm 2 \mathrm{~h}$ at $37^{\circ} \mathrm{C}$ with shaking at $150 \mathrm{rpm}$. About 1 milliliter of the dilution sample and 1 milliliter of the exponentially growing WG 49 host culture were added to molten Semi-solid TYGA. This was mixed and poured into a petri dish. When higher bacterial background flora may have interfered with the growth of the host and replication of phages, nalidixic acid and kanamycin was added to suppress contaminant growth. The overlays were incubated over-night at $37^{\circ} \mathrm{C}$. The bacteriophage $\mathrm{Q} \beta$ concentrations reported in the plaque forming unit (PFU) were average from the triple plate count that illustrated a standard deviation of less than $30 \%$. The detection limit of the plaque assay, which corresponds to the smallest amount of phages that could be detected, was $1 \mathrm{PFU} / \mathrm{ml}$. 


\section{Results and Discussion}

\subsection{Raw Water Characteristics}

The characteristics of the raw water from the Ping River were analyzed. The average $\mathrm{pH}$ and alkalinity values of the Ping River water were 7.69 and $108.87 \mathrm{mg} / \mathrm{l} \mathrm{CaCO}$, respectively. It can be noticed that the $\mathrm{pH}$ of the raw water was nearly neutral. In order to prevent $\mathrm{pH}$ drops during the coagulation/flocculation process, conventional water coagulation uses alum (aluminum sulfate) as the coagulant was generally required the additional alkalinity in case of low alkalinity raw water. PACl are synthetic polymers dissolved in water that react to form insoluble aluminium poly-hydroxides. $\mathrm{PACl}$ solutions are not as acidic as alum. Therefore, $\mathrm{PACl}$ was induced as the coagulant without $\mathrm{pH}$ adjustments in this study. The turbidity of the raw water was 41.77 NTU, which is considered low. This is because the raw water in this study was collected in the winter.

The concentration of bacteriophage $\mathrm{Q} \beta$ in the raw water samples was observed to be under the detection limit. As a result, it was necessary to apply a larger water sample volume in the plaque assay and/or apply the virus concentration method in order to increase the bacteriophage $Q \beta$ concentration in the water samples prior to the plaque assay. Thus, bacteriophage $\mathrm{Q} \beta$ was spiked in all experiments according to the recommendation of U.S. Environmental Protection Agency, regarding the control of the quality of treated surface water by membrane filtration. The virus feed concentration has to be sufficiently high to allow the demonstration of up to $6.5 \log$ removal when the surrogate is removed to the detection limit.

\subsection{Removal of Bacteriophage $Q \beta$ by In-line Coagulation with Ceramic Membrane}

The efficiency of the bacteriophage $\mathrm{Q} \beta$ removal process can be expressed by the log removal, which is defined as $\log \mathrm{Ci} / \mathrm{Cf}$, where $\mathrm{Ci}$ and $\mathrm{Cf}$ represent the bacteriophage initial concentration and the bacteriophage in the filtrate water, respectively. Figure 2 illustrates the log removal of bacteriophage Q $\beta$ by the ceramic membrane with and without $\mathrm{PACl}$ coagulation.

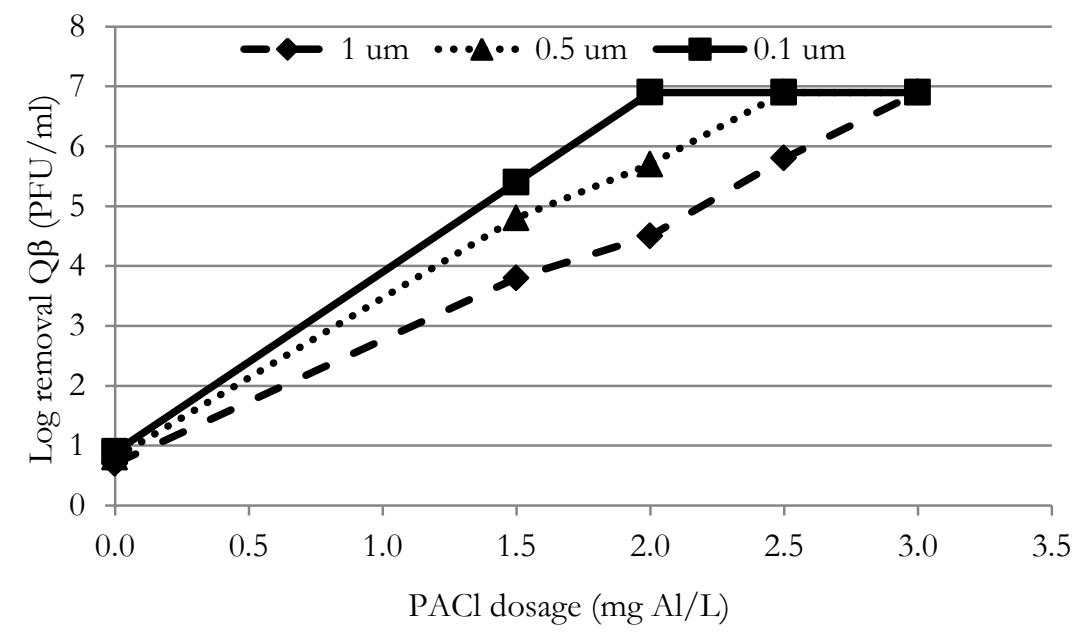

Fig. 2. The log removal of bacteriophage $\mathrm{Q} \beta$ by the ceramic membrane with and w/o coagulation.

In this study, raw water was spiked with bacteriophage $\mathrm{Q} \beta$ at $8.00 \mathrm{x} 106 \mathrm{PFU} / \mathrm{ml}$. The effect of the pore size of the ceramic microfiltration membrane on bacteriophage $\mathrm{Q} \beta$ removal was studied. The results show that the bacteriophage $\mathrm{Q} \beta$ concentrations were reduced from $8.00 \times 10^{6} \mathrm{PFU} / \mathrm{ml}$ in the spiked raw water to $1.78 \times 10^{6} \mathrm{PFU} / \mathrm{ml}, 1.18 \times 10^{6} \mathrm{PFU} / \mathrm{ml}$ and $9.33 \times 10^{5} \mathrm{PFU} / \mathrm{ml}$ by ceramic membrane with pore sizes of 1.0 $\mu \mathrm{m}, 0.5$ and $0.1 \mu \mathrm{m}$, respectively. The log removal of the three pore sizes of ceramic membranes without $\mathrm{PACl}$ coagulants were lower than 1.

Since the diameter of the bacteriophage $\mathrm{Q} \beta(0.023 \mu \mathrm{m})$ was smaller than the ceramic membrane pore sizes [19], a bacteriophage $\mathrm{Q} \beta$ removal of lower than $1 \log$ removal was observed in a previous study. 
According to several studies, ceramic membrane cannot be expected to be an effective barrier for virus sized particles based on their nominal pore sizes. Two mechanisms, however, are recognized: (a) removal by the filtration effect of the fouling layer on the membrane surface, and (b) the aggregation of virus particles into larger particles and thus improved rejection [20].

In order to enhance the efficiency of bacteriophage $\mathrm{Q} \beta$ removal, the in-line coagulation with ceramic membrane filtration was conducted. The results of in-line coagulation at $\mathrm{PACl}$ dosages 1.5, 2.0, 3.5 and 3.0 $\mathrm{mg}-\mathrm{Al} / \mathrm{L}$ with the $1.0 \mu \mathrm{m}$ pore-sized ceramic membrane show that it can remove bacteriophage $\mathrm{Q} \beta$ at an initial concentration of $8.00 \times 10^{6} \mathrm{PFU} / \mathrm{ml}$ to $1.23 \times 10^{3}, 2.56 \times 10^{2}, 1.20 \times 10^{1}$ and $1.00 \times 10^{0} \mathrm{PFU} / \mathrm{ml}$, respectively. Similarly, in-line coagulation with the $0.5 \mu \mathrm{m}$ pore-sized ceramic membranes could remove bacteriophage $\mathrm{Q} \beta$ from an initial concentration of $8.00 \times 10^{6} \mathrm{PFU} / \mathrm{ml}$ to $1.16 \times 10^{2}, 1.60 \times 10^{1}, 1.00 \times 10^{0}$ and $1.00 \times 10^{0} \mathrm{PFU} / \mathrm{ml}$, respectively. Meanwhile, the $0.1 \mu \mathrm{m}$ pore sized ceramic membrane showed that it could remove bacteriophage $\mathrm{Q} \beta$ from an initial concentration of $8.00 \times 10^{6} \mathrm{PFU} / \mathrm{ml}$ to $3.20 \times 10^{1}, 1.00 \times 10^{0}$, $1.00 \times 10^{0}$ and $1.00 \times 10^{\circ} \mathrm{PFU} / \mathrm{ml}$, respectively.

The resulted shows that the addition of the $\mathrm{PACl}$ coagulant could enhance the removal of bacteriophage $\mathrm{Q} \beta$. From the log removal results in Fig. 2, it can be seen that increasing the PACl dosage can enhance the log removal of bacteriophage $\mathrm{Q} \beta$ to the highest $\log$ removal as 6.9. The results show that the removal of the bacteriophage $\mathrm{Q} \beta$ concentration increased from $0.7 \log$ removal by the $1.0 \mu \mathrm{m}$ poresized ceramic microfiltration membrane to 3.8, 4.5, 5.8 and 6.9 log removal at the PACl dosages of 1.5, 2.0, 2.5 and $3.0 \mathrm{mg}-\mathrm{Al} / \mathrm{L}$, respectively. Similarly, the removal of the bacteriophage $\mathrm{Q} \beta$ concentration by the 0.5 $\mu \mathrm{m}$ pore-sized ceramic microfiltration membrane also increased from 0.8 to 4.8, 5.7, 6.9 and $6.9 \mathrm{log}$ removal at the $\mathrm{PACl}$ dosages of $1.5,2.0,2.5$ and $3.0 \mathrm{mg}-\mathrm{Al} / \mathrm{L}$, respectively. The smallest pore size $(0.1 \mu \mathrm{m})$ presented the highest log removal. The log removal increased from 0.9 to 5.4, 6.9, 6.9 and 6.9 at the $\mathrm{PACl}$ dosages of 1.5, 2.0, 2.5 and $3.0 \mathrm{mg}-\mathrm{Al} / \mathrm{L}$, respectively. High bacteriophage $\mathrm{Q} \beta \log$ removal was obtained from smallest pore size membrane even at the low $\mathrm{PACl}$ dosage.

The ceramic membrane microfiltration at all pore sizes with the lowest $\mathrm{PACl}$ dose $(1.5 \mathrm{mg}-\mathrm{Al} / \mathrm{L})$ could not reduce bacteriophage $\mathrm{Q} \beta$ completely. Bacteriophage $\mathrm{Q} \beta$ weakly absorbed to aggregates and passed through the membrane. The ceramic membrane with a pore size of $0.1 \mu \mathrm{m}$ achieved a log removal of 6.9 with a $\mathrm{PACl}$ dose of $2.0 \mathrm{mg}-\mathrm{Al} / \mathrm{L}$. Meanwhile, the ceramic membrane with a pore size of $1.0 \mu \mathrm{m}$ showed lower performances $(4.5 \mathrm{log})$. These results corresponded to those of [4] which reported that the coagulant dosage strongly affected virus removal with the coagulation-MF hybrid system: the larger the coagulant dose, the greater the proportion of virus was removed.

From a review of literature, removal mechanisms for enteric viruses by membrane filtration have taken into account size exclusion, the electrostatic repulsion between a charged membrane and a charged virus, and the adsorption of viruses to the membrane material. It can be described that $\mathrm{PACl}$ coagulation with a ceramic membrane might contribute to bacteriophage $Q \beta$ removal by adsorption or attraction on suspended $\mathrm{PACl}$ with enough adsorption potential. Bacteriophage $\mathrm{Q} \beta$ capture in the $\mathrm{PACl}$ cake layer and are clogging in the constricted membrane pore, including membrane physical sieving. In addition, clay particles naturally contain a negative charge, when the amino acid-RNA composition of bacteriophage $\mathrm{Q} \beta$ is also negatively charged due to the $\mathrm{pH}$ of the surface water $(\mathrm{pH} 7-8)$ [21]. Therefore, bacteriophage $\mathrm{Q} \beta$ could not be absorbed with clay particles without a coagulant. PACl could reduce the negative charge of the amino acid so that it could reach its isoelectric point (no charge amino acid). Then the amino acid-RNA composition could become non-charged and adsorbed onto negatively charged clay particles to form larger aggregates.

Coagulation effectively aggregated bacteriophage $\mathrm{Q} \beta$ to form larger sized aggregates and also increased the coagulation time. Therefore, the aggregated bacteriophage $\mathrm{Q} \beta$ was large enough to be retained on the ceramic membrane surface. Thus, coagulation at the $\mathrm{PACl}$ doses of $3.0 \mathrm{mg}-\mathrm{Al} / \mathrm{L}, 2.5 \mathrm{mg}-\mathrm{Al} / \mathrm{L}$ and $2.0 \mathrm{mg}-$ $\mathrm{Al} / \mathrm{L}$ combined with ceramic membrane microfiltration offered the best conditions for bacteriophage $\mathrm{Q} \beta$ reduction with the three membranes $(1.0 \mu \mathrm{m}, 0.5 \mu \mathrm{m}$, and $0.1 \mu \mathrm{m})$ when the initial concentration of bacteriophage $\mathrm{Q} \beta$ was $8.00 \times 10^{6} \mathrm{PFU} / \mathrm{ml}$.

\subsection{Removal of Bacteriophage $Q \beta$ with Different an Initial Concentration by In-line Coagulation with Ceramic Membrane Microfiltration}

This part investigates the effect of different an initial concentrations of bacteriophage $Q \beta$ in the feed water on the bacteriophage $\mathrm{Q} \beta$ removal. The different initial concentrations were varied at $5.00 \times 10^{5} \mathrm{PFU} / \mathrm{ml}$, $4.00 \times 10^{6} \mathrm{PFU} / \mathrm{ml}$ and $8.00 \times 10^{7} \mathrm{PFU} / \mathrm{ml}$. Three pore sizes of ceramic membranes $(1.0 \mu \mathrm{m}, 0.5 \mu \mathrm{m}$ and 1 
$\mu \mathrm{m})$ were used and the $\mathrm{PACl}$ concentrations were varied at 1.5, 2.0, 2.5 and $3.0 \mathrm{mg}-\mathrm{Al} / \mathrm{L}$. The results of the bacteriophage $\mathrm{Q} \beta$ reduction at different an initial bacteriophage $\mathrm{Q} \beta$ concentrations are shown in Fig. 3.

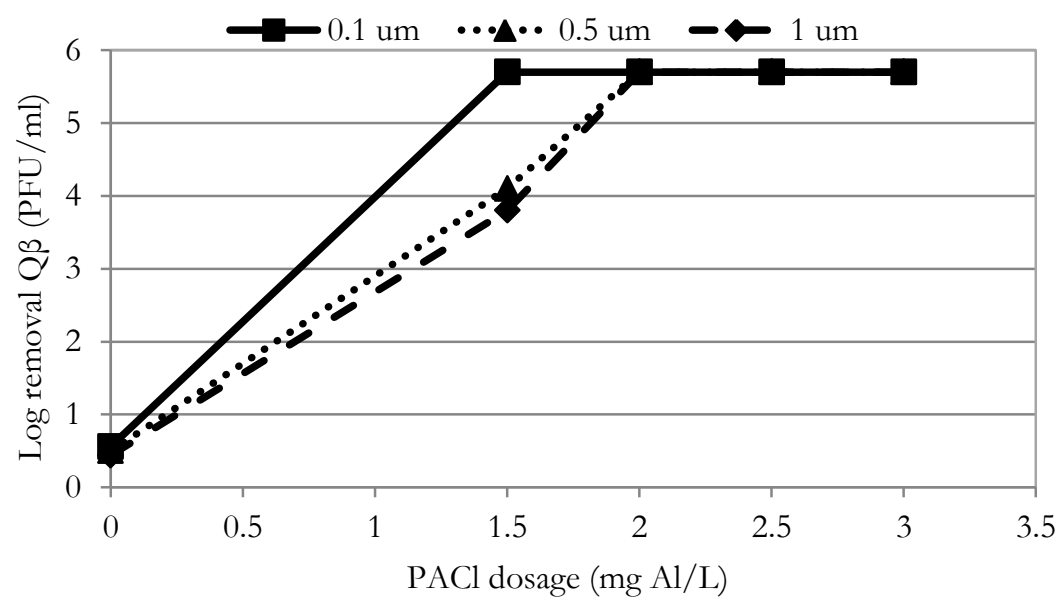

(a) initial bacteriophage $\mathrm{Q} \beta$ concentration of $5.00 \times 10^{5} \mathrm{PFU} / \mathrm{ml}$

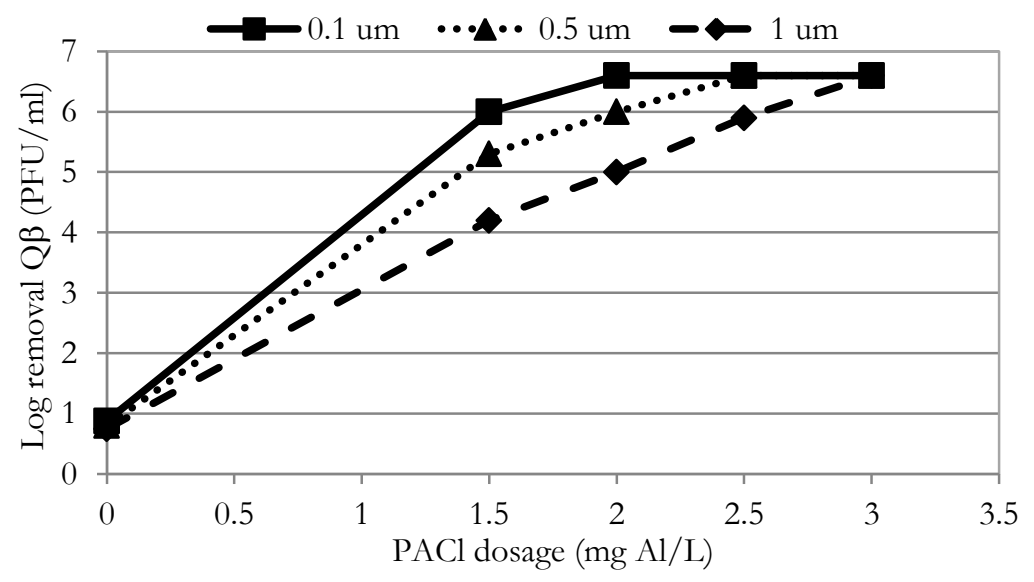

(b) initial bacteriophage $\mathrm{Q} \beta$ concentration of $4.00 \times 10^{6} \mathrm{PFU} / \mathrm{ml}$

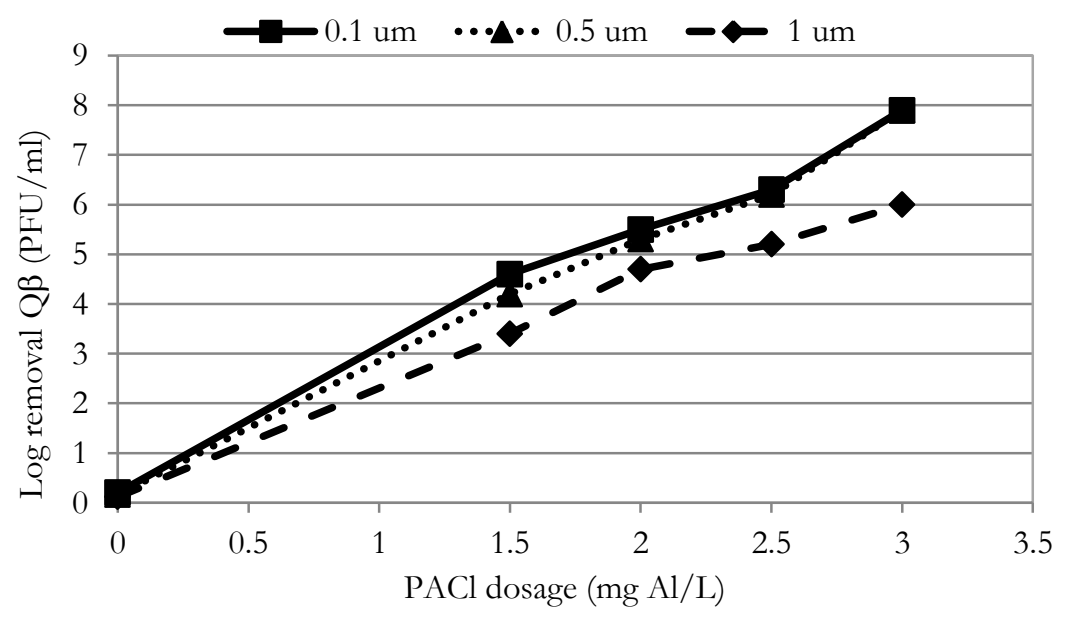

(C) initial bacteriophage $\mathrm{Q} \beta$ concentration of $8.00 \times 10^{7} \mathrm{PFU} / \mathrm{ml}$

Fig. 3 The log removal of bacteriophage $Q \beta$ by in-line coagulation with ceramic membrane filtration at different an initial bacteriophage $\mathrm{Q} \beta$ concentrations. 
The results from Fig. 3 show that the bacteriophage $\mathrm{Q} \beta$ in the spiked raw water at $5.00 \mathrm{x} 10^{5} \mathrm{PFU} / \mathrm{mL}$ was completely retain by the $0.1 \mu \mathrm{m}$ ceramic membrane at all $\mathrm{PACl}$ dosages. It also achieved the highest log removal efficiency $(5.7 \mathrm{log})$. On the other hand, bacteriophage $\mathrm{Q} \beta$ remained present in the filtrate of the larger pore-sized ceramic membranes at the lowest $\mathrm{PACl}$ dose $(1.5 \mathrm{mg}-\mathrm{Al} / \mathrm{L})$. To remove all bacteriophage $\mathrm{Q} \beta$ in the spiked raw water, the $0.5 \mu \mathrm{m}$ and $1.0 \mu \mathrm{m}$ pore-sized ceramic membranes required a $\mathrm{PACl}$ dosage of $2.0 \mathrm{mg}-\mathrm{Al} / \mathrm{L}$. However, when the initial $\mathrm{Q} \beta$ concentrationwas increased to $4.00 \times 10^{6} \mathrm{PFU} / \mathrm{mL}$, the ceramic membrane pore size $0.1 \mu \mathrm{m}$ with low $\mathrm{PACl}$ dose $(1.5 \mathrm{mg}-\mathrm{Al} / \mathrm{L})$ cannot remove bacteriophage $\mathrm{Q} \beta$ completely. The combination of the $0.1 \mu \mathrm{m}$ pore-sized ceramic membrane with $2.0 \mathrm{mg}-\mathrm{Al} / \mathrm{L}$ allowed for the highest $\log$ removal $(6.6 \mathrm{log})$, which was similar when the higher $\mathrm{PACl}$ doses $(2.5$ and $3 \mathrm{mg}-\mathrm{Al} / \mathrm{L})$ were employed. On the other hand, the ceramic membranes with larger pores $(0.5 \mu \mathrm{m}$ and $1.0 \mu \mathrm{m})$ required more $\mathrm{PACl}$ to totally remove the bacteriophage $\mathrm{Q} \beta$. The most effective $\mathrm{PACl}$ dose for removing bacteriophage $\mathrm{Q} \beta$ completely with the $0.5 \mu \mathrm{m}$ and $1.0 \mu \mathrm{m}$ pore-sized membranes were 2.5 and $3.0 \mathrm{mg}-\mathrm{Al} / \mathrm{L}$, respectively.

For the highest initial bacteriophage $\mathrm{Q} \beta$ concentration at $8.00 \times 10^{7} \mathrm{PFU} / \mathrm{mL}$, the obtained results showed that the highest $\log$ removal $(7.9 \mathrm{log})$ was observed by the highest coagulation $(3.0 \mathrm{mg}-\mathrm{Al} / \mathrm{L})$ combined with 0.5 and $0.1 \mu \mathrm{m}$ pore-sized ceramic membrane. On the other hand, a log removal $(4.6 \mathrm{log})$ was achieved by coagulation with the $0.1 \mu \mathrm{m}$ pore-size ceramic membrane at the low $\mathrm{PACl}$ dose $(1.5 \mathrm{mg}$ $\mathrm{Al} / \mathrm{L})$. This indicated that the growth of aggregates was not sufficiently large enough to remove bacteriophage $\mathrm{Q} \beta$ with low $\mathrm{PACl}$ doses with all the evaluated ceramic membranes. The high initial bacteriophage $\mathrm{Q} \beta$ concentration required a higher $\mathrm{PACl}$ dosage to improve aggregation and its removal efficiency. Increasing the coagulant dosage could make the aggregates adequately large enough to be rejected by the ceramic membrane. Incidentally, the performance of the $1.0 \mu \mathrm{m}$ pore-sized ceramic membrane was lower than those of the smaller pore sizes as bacteriophage $\mathrm{Q} \beta$ was not retained by ceramic membrane microfiltration. The highest $\mathrm{PACl}$ dosage in this study was not able to sufficiently form large enough aggregates of bacteriophage $\mathrm{Q} \beta$ that could be rejected by ceramic membrane microfiltration. A higher $\mathrm{PACl}$ dosage was required to remove bacteriophage $\mathrm{Q} \beta$ in the spiked raw water completely.

Increasing the initial bacteriophage $\mathrm{Q} \beta$ concentration affected the removal of the bacteriophage $\mathrm{Q} \beta$ concentration by ceramic membrane microfiltration. The highest log removal was different following the initial bacteriophage $\mathrm{Q} \beta$ concentration. Increasing the concentration of bacteriophage $\mathrm{Q} \beta$ in the raw water from $10^{5}$ to $10^{7} \mathrm{PFU} / \mathrm{ml}$ affected a more than $1 \log$ drop in removal using coagulation with ceramic membrane microfiltration. The most effective $\mathrm{PACl}$ dosage from a previous study did not suitably remove the concentration of bacteriophage $\mathrm{Q} \beta$. These results relate to those of [22] who noticed that increasing the concentration of bacteriophage in the feed solution from $10^{6}$ to $10^{9} \mathrm{PFU} / \mathrm{ml}$ caused more than a 1 log drop in removal using ultrafiltration. Thus, the bacteriophage $\mathrm{Q} \beta$ in the feed water can have an effect on the removal of bacteriophage $\mathrm{Q} \beta$ of ceramic membrane microfiltration with in-line coagulation.

\section{Conclusion}

Based on the obtained results from this study on bacteriophage $\mathrm{Q} \beta$ removal by in-line $\mathrm{PACl}$ coagulation with ceramic membrane filtration, it can be concluded that ceramic membranes with pore sizes larger than $0.1 \mu \mathrm{m}$ cannot act as a physical barrier to bacteriophage $\mathrm{Q} \beta$. Thus, ceramic membrane microfiltration alone cannot remove this virus in water. $\mathrm{PACl}$ coagulations have a strong effect on bacteriophage $\mathrm{Q} \beta$ removal. The most effective PACl dosages with ceramic membranes with $0.1,0.5$ and $1.0 \mu \mathrm{m}$ pore sizes for bacteriophage $\mathrm{Q} \beta\left(8.00 \times 10^{6} \mathrm{PFU} / \mathrm{mL}\right)$ removal were $2.0,2.5$ and $3.0 \mathrm{mg}-\mathrm{Al} / \mathrm{L}$, respectively. When an initial bacteriophage $\mathrm{Q} \beta$ concentration was $5.00 \times 10^{5} \mathrm{PFU} / \mathrm{ml}$, in-line coagulation with ceramic membrane filtration can retained all bacteriophage $\mathrm{Q} \beta$ from raw water. However, the removal efficiency were decreased with the increasing of an initial bacteriophage $\mathrm{Q} \beta$ to $4.00 \times 10^{6}$ and $8.00 \times 10^{7}$, respectively. The higher initial bacteriophage $\mathrm{Q} \beta$ required a larger $\mathrm{PACl}$ dosage to improve aggregation and the removal efficiency when the larger pore-sized membrane was utilized.

\section{Acknowledgements}

This research was financially supported by the Center of Excellence on Hazardous Substance Management (HSM), Chulalongkorn University. 


\section{References}

[1] D. Boccia, A. E. Tozzi, B. Cotter, C. Rizzo, T. Russo, G. Buttinelli, A. Caprioli, M. L. Marziano, and F. M. Ruggeri, "Waterborne outbreak of Norwalk-like virus gastroenteritis at a tourist resort, Italy," Emerging Infectious Diseases journal, vol. 8, no. 6, pp. 563-568, 2002.

[2] K. Hoebe, E. Jansen, and B. Beutler, "The interface between innate and adaptive immunity," Nature Immunology, vol. 5, pp. 971-974, 2004.

[3] Y. Matsui, T. Matsushita, T. Inoue, M. Yamamoto, Y. Hayashi, H. Yonekawa, and Y. Tsutsumi, "Virus removal by ceramic membrane microfiltration with coagulation pretreatment," Water Science Technology: Water Supply, vol. 3, no. 5, pp. 93-99, 2003.

[4] T. Matsushita, Y. Matsui, and N. Shirasaki, "Effect of membrane pore size, coagulation time, and coagulant dose on virus removal by a coagulation ceramic microfiltration hybrid system," Desalination, vol. 178, pp. 21-26, 2005.

[5] M. Otaki, K. Yano, and S. Ohgaki, "Virus removal in a membrane separation process," Water Science and Technology, vol. 37, no. 10, pp. 107-116, 1998.

[6] N. Shirasaki, T. Matsushita, Y. Matsui, K. Ohno, and M. Kobuke, "Virus removal in a hybrid coagulation-microfiltration system: Investigating mechanisms of virus removal by a combination of PCR and PFU methods," Water Science and Technology: Water Supply, vol. 7, pp. 1-8, 2007.

[7] T. Urase, K. Yamamoto, and S. Ohkagi, "Effect of pore structure of membranes and module configuration on virus retention," Journal of Membrane Science, vol. 115, pp. 21-29, 1996.

[8] N. Contreras-Coll, F. Lucena, K. Mooijman, A. Havelaar, V. Pierzo, M. Boque, A. Gawler, C. Höller, M. Lambiri, G. Mirolo, B. Moreno, M. Niemi, R. Sommer, B. Valentin, A. Wiedenmann, V. Young, and J. Jofre, "Occurrence and levels of indicator bacteriophages in bathing waters throughout Europe," Water Research, vol. 36, pp. 4963-4974, 2002.

[9] F. Lucena, X. Méndez, A. Morón, E. Calderón, C. Campos, A. Guerrero, M. Cárdenas, C. Gantzer, L. Shwartzbrood, S. Skraber, and J. Jofre, "Occurrence and densities of bacteriophages proposed as indicators and bacterial indicators in river waters from Europe and South America," Journal of Applied Microbiology, vol. 94, pp. 808-815, 2003.

[10] L. Ogorzaly and C. Gantzer, "Development of real-time RT-PCR methods for specific detection of Fspecific RNA bacteriophage genogroups: application to urban raw wastewater," Journal of Virological Methods, vol. 138, pp. 131-139, 2006.

[11] E. Haramoto, M. Kitajima, H. Katayama, M. Asami, M. Akiba, and S. Kunikane, "Application of realtime PCR assays to genotyping of F-specific phages in river water and sediments in Japan," Water Research, vol. 43, pp. 3759-3764, 2009.

[12] L. Ogorzaly, A. Tissier, I. Bertrand, A. Maul, and C. Gantzer, "Relationship between F-specific RNA phage genogroups, faecal pollution indicators and human adenoviruses in river water," Water Research, vol. 43, pp. 1257-1264, 2009.

[13] S. Shahriar, A. Amimul, A. A. Abdullah, and A. Thirugnanasambantham, "Physical risk assessment for urban water supply in a developing country: A case of mega city Dhaka," Engineering Journal, vol. 20, no. 3, pp. 23-31, 2016.

[14] S. S. Adham, K. P. Chiu, K. Gramith, and J. Oppenheimer, Development of a Microfiltration and Ultrafiltration Knowledge Base. Pasadena, CA: American Water Works Association Research Foundation, 2005.

[15] S. A. Khemakhem, R. Larbot, and R. Ben Amar, "New ceramic microfiltration membranes from Tunisian natural materials: Application for the cuttlefish effluents treatment," Ceramic International, vol. 35, no. 1, pp. 55-61, 2009.

[16] Y. Dong, S. Chen, X. Zhang, J. Yang, and X. Liu, "Fabrication and characterization of low cost tubular mineral-based ceramic membranes for micro-filtration from natural zeolite," Membrane Science, vol. 281, pp. 592-599, 2006.

[17] P. Rakruam, "Trihalomethane formation potential of DOM fractions in water production by in-line coagulation ceramic membrane microfiltration," dissertation, Environmental Management, Chulalongkorn University, Bangkok, Thailand, 2013.

[18] P. Rakruam and S. Wattanachira, "Reduction of DOM fractions and their trihalomethane formation potential in surface river water by in-line coagulation with ceramic membrane filtration," Journal of Environmental Science, vol. 26, pp. 1-8, 2014. 
[19] Y. Matsui, R. Murase, T. Sanogawa, N. Aoki, S. Mima, T. Inoue, and T. Matsushita, "Micro-ground powdered activated carbon for effective removal of natural organic matter during water treatment," Water Science Technology: Water Supply, vol.4, no. 4, pp. 155-163, 2004.

[20] A. Antony, J. Blackbeard, and G. Leslie, "Removal efficiency and integrity monitoring techniques for virus removal by membrane processes," Environmental Science and Technology, vol. 42, pp. 891-933, 2012.

[21] E. M. Van Voorthuizen, N. J. Ashbolt, and A. I. Schafer, "Role of hydrophobic and electrostatic interactions for initial enteric virus retention by MF membranes," Journal of Membrane Science, vol. 194, pp. 69-79, 2001.

[22] J. G. Jacangelo, S. S. Adham, and J. M. Laîné, "Mechanism of Crytosporidium, Giardia, and MS2 virus removal by MF and UF," American Water Works Association, vol. 87, no. 9, pp. 107-121, 1995. 